\title{
MIĘDZY ARCHIWISTYKĄ A ARCHITEKTURĄ INFORMACJI
}

\section{Słowa kluczowe}

archiwistyka; zarządzanie dokumentacją; nauka o informacji; architektura informacji; informatologia

\section{Keywords}

archival science; records management; information science; information architecture

\section{Streszczenie}

Archiwistyka, informatologia, zarządzanie dokumentacją i zarządzanie informacją to nauki pokrewne. W ostatnim czasie pojawiły się tendencje do scalenia ich w ramach nauki o informacji uznając, że mimo pewnych różnic w każdym obszarze mamy do czynienia z informacją. Stanowi to duże uproszczenie problemu, a doszukiwanie się bezpośrednich korzeni nauki o informacji w działalności archiwów jest kolejnym niedopowiedzeniem, bowiem pomija archiwistykę wyrosłą na praktycznej działalności archiwów oraz sta-

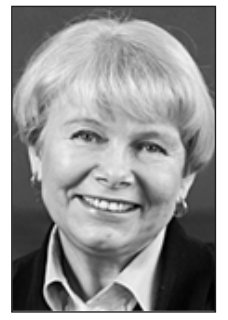

Wanda Krystyna Roman. Profesor zwyczajny, kierownik Zakładu Zarządzania Dokumentacją i Informacji Archiwalnej UMK. Jej zainteresowania badawcze obejmują informację archiwalną, kulturę informacyjną i dokumentacyjną, archiwa polskie za granicą oraz archiwa wojskowe. internowania Polaków podczas II wojny światowej, biografistykę oraz edytorstwo źródeł historycznych. Jest autorką m.in. monografii: Centralne Archiwum Wojskowe 1918-1998. Tradycje, historia, wspótczesność stużby archiwalnej Wojska Polskiego (Toruń 1999) oraz ostatnio Wspótczesna kultura dokumentacyjna (Toruń 2013).

E-mail: wandakr@umk.pl

ORCID ID: 0000-0002-5648-4273 
nowiącą wyraźnie odrębny obszarem badawczym obejmującym archiwa i archiwalia. Nie kwestionując słusznych argumentów za uznaniem archiwistyki jako nauki informacyjnej, należy podkreślić, że tylko jeden z jej działów - informacja archiwalna powstająca w wyniku opracowania archiwaliów - jest obszarem wspólnym z informatologią. Podobnie rzecz wygląda z zarządzaniem dokumentacją, które zrodziło się na gruncie badań działalności kancelarii i biur oraz obiegu dokumentacji od jej wytworzenia do zniszczenia lub wieczystego zarchiwizowania. Niezależnie od nowoczesnych technologii informacyjno-telekomunikacyjnych, które wywarły istotny wpływ na sposoby tworzenia i przekazywania dokumentacji oraz inne czynności kancelaryjne, a także na sposób wykonywania funkcji przez archiwa, specyfika archiwistyki i zarządzania dokumentacją, decydująca wcześniej o ich odrębności, pozostała. Możliwa jest natomiast współpraca ze specjalistami z nauki o informacji, z architektami informacji odnośnie do działalności praktycznej - czyli zarządzania dokumentacją i informacją archiwalną w sieci.

\section{Summary}

\section{Between archival science and information architecture}

Archival science, information science, records management, and information management are allied sciences. Recently, there are tendencies to merge them into information science, recognising, that despite some differences, every field copes with information. It is a big simplification of the problem, and searching for direct roots of information science in works of archives is another understatement, because this approach does not see archival science as grown from practical works of archives and having explicitly separate research object, which are archives and archival materials. Not contesting fair arguments for seeing archival science as one of information sciences, it must be stressed, that only one of its divisions - archival information resulted from arrangement and description of archival materials - is a research object shared with information science. The situation is similar with records management, that was born on the ground of studying works of offices and records circulation, from creation until their destruction or archiving permanently. Regardless of modern information and communication technologies, that substantially influenced methods of creating and passing on records, and other office works, as well as the way archives perform their functions, the specific nature of archival science and records management, that previously determined their autonomy, still remains. The cooperation with specialists of information science, with information architects is possible in accordance to practice - which is records management and archival information on the Web.

$(\mathrm{D}))_{\mathrm{i}}^{\circ}$

o napisania niniejszego tekstu zainspirowały, ale również sprowokowały i zaniepokoiły mnie - archiwistę i historyka z wykształcenia, z kilkunastoletnim stażem pracy w archiwum, prawie dwudziestoletnim okresem pracy dydaktycznej na kierunku archiwistyka i zarządzanie dokumentacją, równolegle prowadzącego badania naukowe - fragmenty pierwszego artykułu - z ponad dwudziestu zawartych w zbiorowej monografii pt. Nauka o informacji - au- 
torstwa Mirosława Górnego pt. Nauka o informacji jako dyscyplina naukowa ${ }^{1}$. Fragmenty tego artykułu stały się punktem odniesienia do szerszych rozważań na temat rozwoju takich dziedzin nauki, jak archiwistyka, zarządzanie dokumentacją, czy informatologia (informacja naukowa) oraz zmian w ich postrzeganiu, a także postrzeganiu ich przedmiotu badań zachodzących w warunkach współczesnego społeczeństwa nazwanego informacyjnym. Novum, niezależnym od wspomnianego artykułu, jest uwzględnienie architektury informacji, w ostatnich latach zauważonej w Polsce i uważanej za naturalny kierunek ewolucji informatologii. Uwagi poniższe jedynie po części mają charakter recenzyjny, zdecydowanie częściej refleksyjny, a mam nadzieję, że przede wszystkim skłaniający do dyskusji nad zakresem współczesnych dyscyplin naukowych, ich przenikaniem się, obszarów wspólnych, ale i samodzielności opartej o wieloletnie doświadczenia, dorobek badawczy i metodologię. Nie pretendują poniższe rozważania do bycia obiektywną prawdą, a raczej wskazują na rozterki wynikające z potrzeby (konieczności) zajęcia stanowiska w obliczu zmian zachodzących w nauce o informacji. Tekst dotyczy archiwistyki, zarządzania dokumentacją, zarządzania informacją, informatologii (informacji naukowej) oraz architektury informacji - $\mathrm{w}$ różnych proporcjach, ze szczególnym uwzględnieniem genezy każdej nauki (głównie w odniesieniu do polskiej rzeczywistości, ale w powiązaniu z trendami światowymi), obszarów wspólnych i jednocześnie prawa do zachowania niezależności w obrębie swojej dziedziny naukowej oraz postrzegania w kontekście zmian technologicznych i narodzin społeczeństwa informacyjnego.

Autor wspomnianego artykułu, Mirosław Górny, jest kierownikiem Zakładu Systemów Informacyjnych w Instytucie Językoznawstwa na Wydziale Neofilologii Uniwersytetu Adama Mickiewicza w Poznaniu. Mam wiele uznania dla Niego za podjęcie się niełatwego zadania określenia genezy, przedmiotu i zakresu nauki o informacji oraz naukowoznawczego spojrzenia na tę, względnie młodą, dyscyplinę. Do pewnego stopnia udało się Autorowi osiągnąć postawiony cel. Jednak - w moim przekonaniu - oparcie się jedynie o literaturę anglojęzyczną, co wydaje się być zwyczajem Górnego ${ }^{2}$, zawierającą dorobek naukowy powstały $\mathrm{w}$ innych warunkach kulturowych i organizacyjnych, na podstawie, innych

1 M. Górny, Nauka o informacji jako dyscyplina naukowa, [w:] Nauka o informacji, red. W. Babik, Warszawa 2016, s. 24.

2 Por.: tenże, O formułowaniu problemów badawczych $w$ nauce o informacji, [w:] Nauka o informacji $w$ okresie zmian, red. B. Sosińska-Kalata i E. Chuchro przy współpr. M. Luterka, Warszawa 2013, s. 43-51. 
niż polskie, doświadczeń ${ }^{3}$, może sugerować, że są to doświadczenia jedyne, a w Polsce do tej pory była to biała plama - w wypadku omawianego artykułu stanowi to nader istotny mankament rozważań. Autor nie odniósł się w żaden sposób do bogatego - obejmującego setki publikacji - krajowego dorobku badawczego z zakresu informacji naukowej (informatologii), w tym chociażby: Marii i Kazimierza Leskich ${ }^{4}$, Wojciecha Piroga ${ }^{5}$, Jerzego Ratajewskiego ${ }^{6}$, Marii Dembowskiej $^{7}$, a z nowszych, Hanny Batorowskiej ${ }^{8}$, Barbary Sosińskiej-Kalata ${ }^{9}$, Sabiny Cisek ${ }^{10}$, czy Małgorzaty Janiak ${ }^{11}$, a nawet podręcznika własnego współautorstwa ${ }^{12}$. W tych pracach nie tylko pokazano narodziny nauki o informacji w świecie i w Polsce, ale również zawiłości terminologiczne (w tym kwestia tłumaczenia z języka angielskiego terminu information science: nauka o informacji czy informacja naukowa), skomplikowane często powiązania z innymi naukami czy obszarami badawczymi oraz - w związku z rozwojem technologii informatycznych i przenoszeniem działalności informacyjnej do sieci - stopniowe poszerzanie zakresu, przedmiotu i metod badań. Ponadto Autor nie uwzględnił badań z zakresu informacji prowadzonych w ramach poszczególnych nauk,

3 Podstawowe wykorzystane teksty to: C. Burke, History of Information Science, „Annual Reviev of Information Science and Technology”, vol. 41, iss. 1, 2007, s. 3-53; M.K. Buckland, Z. Liu, History of information science, „Annual Review of Information Science and Technology" vol. 30, 1995, s. 385-416.

4 M. Leska, K. Leski, Informacja naukowa jako dziedzina wiedzy, „Zagadnienia Informacji Naukowej" nr 1, 1972, s. 7-28.

5 W. Piróg, Zagadnienia informacji i dokumentacji naukowej, Warszawa 1977.

6 J. Ratajewski, Wybrane problemy metodologiczne informologii nauki (informacji naukowej), Katowice 1994.

7 M.in. M. Dembowska, Dokumentacja i informacja naukowa. Zarys problematyki i kierunki rozwoju, Warszawa 1965; taż, Nauka o informacji naukowej (informatologia). Organizacja i problematyka badań w Polsce, Warszawa 1991.

${ }_{8}$ M.in. H. Batorowska, B. Czubała, Wybrane zagadnienia nauki o informacji i technologii informacyjnej, Kraków 1996.

9 M.in. B. Sosińska-Kalata, Wspótczesne oblicze nauki o informacji w Polsce i za granica, [w:] Studia z informacji naukowej i dyscyplin pokrewnych, Katowice 2007, s. 93-119; taż, Ewolucja koncepcji informatologii (nauki o informacji), [w:] Teoretyczne zagadnienia bibliologii i informatologii. Studia i szkice, red. E. Gondek, Katowice 2015, s. 115-137.

10 M.in. S. Cisek, Podstawy teorii $i$ metodologii informatologii, http://docplayer. pl/63276812-Podstawy-teorii-i-metodologii-informatologii.html (dostęp: 12.02.2018); taż, Informatologia $w$ drugim dziesięcioleciu XXI w. Przedmiot, pole badawcze i miejsce w systemie nauk. Aneks. 2: Nauka o informacji, czyli o czym?, https://www.slideshare. net/sabinacisek/cisek-xii-forum-2013 (dostęp: 12.06.2018).

${ }_{11}$ M. Janiak, Informacja naukowa w Polsce na przełomie XX i XXI wieku: dynamika zmian $w$ świetle piśmiennictwa, Kraków 2010.

12 M. Górny, P. Nowak, Wstęp do informacji naukowej, Poznań 1989. 
np. prawnych, ekonomicznych, społecznych, które pozwoliłyby na wyjaśnienie kwestii nierozstrzygniętych ${ }^{13}$. Wreszcie, nie zauważył obszernego piśmiennictwa archiwistycznego, które w większym lub mniejszym stopniu porusza kwestie nie tylko archiwistyki jako nauki informacyjnej, ale i funkcjonowania w jej obrębie działu związanego z informacją archiwalną, którego obecność ugruntowała się wraz ze specjalistyczną terminologią w obszarze badań archiwalnych ${ }^{14}$. Dotyczy to również zarządzania dokumentacją (czy dawniej - biurowości) oraz zarządzania informacją - segmentów nauki o zarządzaniu, ale odnoszących się do specyficznych zasobów informacyjnych oraz mających doświadczenia i dorobek również na gruncie krajowym ${ }^{15}$.

W podstawowym - w pewnym sensie - dla całej monografii tekście, mającym na celu określenie, czym jest nauka o informacji, co jest przedmiotem badań, jaki zakres obejmuje oraz jakimi metodami badawczymi się posługuje w badaniach swojego przedmiotu i jaki ma dzisiaj dorobek naukowy w postaci opublikowanych wyników badań, w miejsce akademickiego wykładu, czytelnicy otrzymali niełatwy w odbiorze esej, z kilkoma tezami i stwierdzeniami, obok których nie sposób przejść obojętnie. Aczkolwiek Autor zastrzega się, że na wiele pytań brak odpowiedzi jednoznacznych, co często podkreśla, to wydaje się, że odnośnie do niektórych, wątpliwości dzisiaj nie powinno być, chociaż niektóre twierdzenia mogą/powinny zostać otwarte.

Bez wątpienia nauka o informacji jest dzisiaj niezaprzeczalnym faktem. Jej dzisiejsza złożoność wynika z procesów doświadczanych przez ludzkość stopniowo wkraczającą w epokę informacji, których kulminacja nastąpiła w drugiej połowie XX w. Na współczesnym obliczu nauki o informacji piętno odcisnęły setki

${ }^{13}$ M.in.: J. Kulikowski, Informacja i świat, w którym żyjemy, Warszawa 1978; J. Oleński, Ekonomika informacji. Podstawy, Warszawa 2001; tenże, Ekonomika informacji. Metody, Warszawa 2003; P. Fajgielski, Informacja $w$ administracji publicznej. Prawne aspekty gromadzenia, udostępniania i ochrony, Wrocław 2007.

14 Przede wszystkim: M. Gołembiowski, System informacji archiwalnej, WarszawaŁódź 1985; tenże, Wprowadzenie do informacji naukowej dla archiwistów, Toruń 1991; B. Ryszewski, Problemy i metody badawcze archiwistyki, Toruń 1985; S. Nawrocki, Archiwum jako ośrodek informacji, [w:] tenże, Archiwistyka i regionalizm, Poznań 1995, s. 285-296.

15 W obszarze zarządzania dokumentacją to m.in. H. Robótka, Wspótczesna biurowość. Zagadnienia ogólne, Toruń 2010; Wspótczesna dokumentacja urzędowa, red. H. Robótka, Toruń 2011; Wspótczesna biurowość w administracji publicznej, red. H. Robótka, Toruń 2013; K. Stryjkowski, Vademecum kancelaryjno-archiwalne, Poznań 2011. W obszarze zarządzania informacją to m.in. R. Zygała, Podstawy zarządzania informacją $w$ przedsiębiorstwie, Wrocław 2007; Podstawy zarządzania informacją, red. J. Czekaj, Kraków 2012. 
lat, zanim się narodziła w znanym dzisiaj kształcie, a wcześniej wykształciły się nauki takie, jak archiwistyka czy zarządzanie dokumentacją oraz informacja naukowa - jak ją nazywano w Polsce przez dziesięciolecia. Mirosław Górny, dając cokolwiek powierzchowny i uproszczony wywód narodzin nauki o informacji i uzasadniając jej wyodrębnienie oraz nowy kształt (zakres), popełnił kilka błędów, a sięgając w odległą przeszłość zmarginalizował fakt, że to nie informację ludzie gromadzili, ale akta w archiwach czy książki w bibliotekach. Informacyjne myślenie o zasobach tych instytucji to dopiero zdobycz XX w. Z jednej strony pisze, że: „Ludzkość jednak nauczyła się rejestrować niektóre rodzaje informacji i gromadzić je poza układem, który je wytwarza. To spowodowało zapewne konieczność zajmowania się informacją jako osobnym elementem rzeczywistości, czego dowodem jest np. powstanie bibliotek czy archiwów", ale dalej konkluduje: „to też ostatecznie przyczyniło się do postrzegania informacji jako odrębnego obiektu." 16

Zanim dostrzeżono, że tak naprawdę obiektem zainteresowania człowieka jest informacja, dopóki możliwe było jej odczytanie tylko dzięki utrwaleniu na nośnikach fizycznych, to praktyka gromadzenia i przechowywania oraz udostępniania tychże nośników dała podwaliny takim naukom, jak archiwistyka czy informacja naukowa (informatologia). Przez setki lat nie postrzegano informacji jako odrębnego pojęcia, a nawet jako elementu dokumentu. Nawet wcześniejsze nazwy informatologii - dokumentacja, dokumentologia, dokumentacja naukowa ${ }^{17}$ - wyraźnie to potwierdzają.

Nie jest prawdą w przypadku archiwów, że gromadzenie archiwaliów odbywało się dopiero „poza układem” (czy układ w rozumieniu Autora oznacza archiwa historyczne, czyli poza instytucją, która je wytworzyła?), ponieważ aż do drugiej połowy XVIII w..$^{18}$ istniały archiwa bieżące w strukturach instytucji, które zbierały dokumentację własną powstałą w toku jej działalności. Na tym obszarze na początku XX w. wykształciło się zarządzanie dokumentacją, natomiast na gruncie archiwów historycznych („poza układem”) narodziła się archiwistyka. Samo pojęcie „poza układem” nie jest chyba dostatecznie czytelne dla mniej obeznanego czytelnika, a oznacza instytucje zajmujące się gromadzeniem

16 M. Górny, Nauka o informacji, s. 24.

17 Por. S. Cisek, Podstawy teorii i metodologii informatologii.

18 Momentem przełomowym było powołanie w porewolucyjnej Francji w 1790 r. Archiwum Narodowego, które jako odrębna instytucja było pierwszym archiwum historycznym w Europie nastawionym na wieczyste przechowywanie akt różnych twórców. Pierwsze polskie archiwum nowego typu - Archiwum Ogólne Krajowe w Warszawie powołano w $1808 \mathrm{r}$. 
i udostępnianiem źródeł informacji (a tym samym informacji) z różnych źródeł, co oznacza wykonywanie różnego rodzaju opracowań metainformacyjnych (informacja o informacji i o źródłach informacji) - czyli bibliotek i archiwów.

Szczególnie kontrowersyjny dla archiwisty fragment artykułu brzmi: „statuty i konstytucje sejmowe z XV i XVI w. w Polsce nakazywały przechowywać księgi sądowe w odpowiedni sposób [...] Inaczej mówiąc, opracowując optymalne z pewnego punktu widzenia zasady przechowywania wspomnianych dokumentów, wykorzystano dostępną wiedzę i naukowe metody. I tak powstał spory fragment wiedzy wchodzącej w skład dyscypliny zwanej nauką o informacji." ${ }^{19}$

Jest to duże uproszczenie skomplikowanego procesu, który doprowadził do ukształtowania się w XX w. nauki zwanej information science, rozumianej szeroko jako nauka o informacji obejmująca całokształt zagadnień teoretycznych i praktycznych związanych z działalnością informacyjną (selekcją, gromadzeniem, przechowywaniem, przetwarzaniem, udostępnianiem informacji). Teza o genezie nauki o informacji (w bardzo szerokim rozumieniu) tkwiącej w działalności archiwów jest o tyleż prawdziwa, co nieprawdziwa. Prawdziwa, ponieważ od drugiej połowy XX w. archiwistyka jest postrzegana jako nauka informacyjna, a archiwa jako ośrodki prowadzące działalność informacyjną - chociaż przez niektórych specjalistów z informatologii określanych mianem „specyficznych placówek informacji”"20. Natomiast nieprawdziwa, gdyż najpierw narodziła się archiwistyka jako nauka o archiwach i archiwaliach ${ }^{21}$, której istnienia i rozwoju na przestrzeni kilkuset lat nie można ignorować. Pierwsze europejskie, teoretyczne dzieła archiwistyczne pochodzą z XVI-XVII w., a o archiwistyce - początkowo jako o nauce pomocniczej historii - można mówić od wieku XIX. Jednym z pierwszych obszarów badań teoretycznych archiwistyki było przechowywanie archiwaliów, czyli obiekty, budynki i pomieszczenia oraz ich przystosowanie, sprawy konserwacji, rozmieszczenia i ewidencji archiwaliów.

Chronologicznie ujmując w nieco schematyczny sposób pojawianie się kolejnych nauk, jako następna wykształciła się informacja naukowa, potem zarządzanie dokumentacją i zarządzanie informacją. W tym kontekście warto przywołać

19 M. Górny, Nauka o informacji, s. 24.

20 Np. B. Rudecka-Onichimowska, Poradnik metodyczny do nauki przedmiotu „Źródła informacji, działalność informacyjna”, Warszawa 1997, s. 131.

${ }^{21}$ Długo trwały dyskusje nad nazwą dla tej dziedziny wiedzy, wyrosłej na gruncie praktycznym, która zajmuje się archiwami, ale i archiwaliami, ich gromadzeniem, przechowywaniem, opracowaniem i udostępnianiem. Por. A. Tomczak, Archiwistyka polska (1918-1969). Z dziejów kształtowania się dyscypliny naukowej i jej nazwy, „Rocznik Biblioteki Narodowej" t. 7, 1972, s. 127-159. 
pytanie postawione przez Górnego na początku artykułu: „Czy dyscypliny z nią [nauką o informacji - WKR] spokrewnione wchłoną ją, czy też odwrotnie, to ona rozszerzy swój obszar badawczy?"22

Autor w pewnym sensie już dokonał tego wchłonięcia poprzez ignorowanie istnienia innych nauk. Może przyjął za wykorzystaną literaturą, że archiwalia, biblioteki, firmy oferujące usługi informacyjne stanowią specjalności w ramach szerokiego spojrzenia na naukę o informacji, a nie specjalności spoza niego ${ }^{23}$. Próbując zaś odpowiedzieć na powyższe pytanie, należy zastanowić się, na ile takie „wchłonięcie” jest możliwe i czy dotyczy wszystkich nauk nazwanych „spokrewnionymi”, a na ile bardziej realne i racjonalne jest poszerzenie obszaru badawczego nauki o informacji. Można się zgodzić z wchłonięciem informatologii (chociaż poprawniej - ewolucji tej nauki), ale jeśli chodzi o archiwistykę i zarządzanie dokumentacją, jedynie do pewnego stopnia, przy zachowaniu autonomii każdej z nich. Obie rządzą się specyficznymi zasadami w ramach swojego obszaru badań. W innych warunkach, pod wpływem innych czynników niż w np. w bibliotekach, czy ośrodkach informacyjnych, kształtowały się zasoby archiwów, inne są warunki, procedury i powody wytwarzania dokumentacji w urzędach i instytucjach - co przekłada się na inne sposoby i metody badań. Pozornie dzisiaj mogłoby się wydawać, że te różnice, dzięki technologii informacyjno-telekomunikacyjnej stopniowo się zacierają, ale to jedynie sposób myślenia o tym się zmienia. To jest coś, co przed kilku laty nazwałam myśleniem informacyjnym, a wynikającym $\mathrm{z}$ tego, że funkcjonowanie $\mathrm{w}$ społeczeństwie informacyjnym, posługiwanie się w codziennym życiu i pracy dokumentem i dokumentacją w formie elektronicznej powoduje, że „myślimy raczej „informacyjnie”, a nie „dokumentacyjnie”, głównie z powodu braku tradycyjnego, papierowego nośnika tekstu. Przyzwyczajenie każe nam myśleć „dokument” w przypadku, gdy trzymamy w ręku papier. Jeśli ten sam dokument otrzymamy i przeczytamy przy pomocy komputera, myślimy w kategoriach konkretnego rodzaju wiadomości elektronicznej - e-mail, plik, folder, spam, link, blog - po prostu informacja"24. Jednakże warto pamiętać, że dokument elektroniczny jest w dalszym ciągu dokumentem, spełniającym te same funkcje co tradycyjny oraz powstającym według określonych reguł, zmieniły się zaś narzędzia, dzięki którym zyskał nową postać i oderwał się od stałego nośnika oraz zmieniły się środki, metody i sposoby dzięki którym może być przekazywany, czy udostęp-

\footnotetext{
22 M. Górny, Nauka o informacji, s. 23.

${ }^{23}$ M. Buckland, Z. Liu, dz. cyt.

${ }^{24}$ W. K. Roman, Wspótczesna kultura dokumentacyjna, Toruń 2013, s. 165.
} 
niany (np. systemy EZD). Zarządzanie dokumentacją w dalszym ciągu stanowi zespół zorganizowanych działań skierowanych na tworzenie, gromadzenie, przechowywanie, opracowanie i udostępnianie całości dokumentacji w ciągu całego jej cyklu życia, bez względu na formę, a więc także dokumentów elektronicznych $\mathrm{z}$ uwzględnieniem ich specyfiki. Archiwa cyfrowe, będące $\mathrm{w}$ istocie systemami teleinformatycznymi, wypełniają takie same funkcje, jak tradycyjne - gromadzą, przechowują, opracowują oraz udostępniają cyfrowe zasoby przy całkowitym zautomatyzowaniu tych funkcji ${ }^{25}$.

Inaczej rzecz się ma w przypadku relacji między nauką o informacji a informacją naukową lub informatologią, od początku lat 70. kształtującą swoją tożsamość w Polsce ${ }^{26}$, dziedziną nauki zajmującą się badaniem działalności informacyjnej jako całości lub jej poszczególnych elementów, do zakresu którego zaliczano badanie „procesów powstawania, gromadzenia, przechowywania, przetwarzania i udostępniania informacji naukowych utrwalonych w dokumentach naukowych, zabezpieczania i opracowywania środków i metod działalności informacyjnej w nauce, wykrywania zasadniczych związków między informacją naukową a działalnością informacyjną w nauce i produkcji”27. Informacja naukowa (informatologia) oraz zarządzanie informacją stanowią dzisiaj trzon nauki o informacji, która w nowej, przedstawionej przez Górnego interpretacji, jest w zasadzie nową nazwą informatologii, do której Autor dołączył również archiwistykę i zarządzanie dokumentacją. Z jego tekstu wynika, że nauka o informacji zamierza obie te dziedziny wchłonąć (a dalsze wywody Autora potwierdzają, że w USA już tak się stało), z czym nie można się zgodzić.

Należy zgodzić się z Sabiną Cisek, że sytuacja metodologiczna informatologii jest skomplikowana ze względu na charakter i rodzaje związków z innymi naukami oraz multidyscyplinarność ${ }^{28}$. Przez dziesięciolecia wskazywano na pojęcia i metody badawcze, które wiązały informatologię z: bibliografią, bibliotekoznawstwem, lingwistyką, logiką, psychologią, cybernetyką, fizjologią człowieka, matematyką, ale nie z archiwistyką ani tym bardziej zarządzaniem dokumentacją. O ile jednak archiwistyka od dawna postrzegana jest jako nauka informacyjna, chociaż mająca własny, wyodrębniony przedmiot badań: archiwa i archiwalia, to zarządzanie dokumentacją dopiero z narodzinami społeczeństwa

25 Por. K. Pepłowska, Archiwa cyfrowe $w$ wybranych krajach europejskich, USA i Australii, Toruń 2017, s. 160.

${ }^{26}$ Jej początki w krajach zachodnich, głównie USA, sięgają końca lat 50.

27 J. Ratajewski, dz. cyt., s. 23.

28 S. Cisek, Podstawy teorii i metodologii informatologii. 
informacyjnego i przenoszeniem coraz większej części aktywności człowieka, a więc i działalności biurowej, do przestrzeni wirtualnej, zaczęło być postrzegane „informacyjnie” jako wydzielony i rządzący się specjalnymi prawami, obszar zarządzania informacją - utrwaloną w postaci dokumentacji ${ }^{29}$.

W ramach informacji naukowej wyodrębniano dwa podstawowe zakresy badań: po pierwsze, obejmujące ogólne problemy działalności informacyjnej, bez względu na dziedzinę, której ta działalność dotyczy oraz po drugie, zagadnienia obejmujące działalność informacyjną w poszczególnych dziedzinach wiedzy ${ }^{30}$. Na tej podstawie, specjaliści badacze zajmujący się archiwistyką zwrócili uwagę na znalezienie się archiwistyki w kręgu zainteresowania informacji naukowej (informatologii) prawie równocześnie z zadomowianiem się tej ostatniej w Polsce. Od 1970 r. powoływano w archiwach ośrodki informacji archiwalnej - zajmujące się nie archiwaliami, ale informacją o nich opracowaną metodami naukowymi. Archiwa zaczęto postrzegać jako instytucje zajmujące się działalnością informacyjną, a archiwistyka poszerzyła swój zakres badań o kolejny dział informację archiwalną. Wzajemne związki archiwistyki i informacji naukowej, przeanalizował ponad 30 lat temu Bohdan Ryszewski. Wychodząc z założenia, że działalność informacyjna - przedmiot informatologii - jest właściwa również dziedzinie archiwalnej, ta ostatnia - jego zdaniem - „może być, a nawet w pewnym zakresie już jest [rok 1985 - WKR] obiektem penetracji badawczej informacji naukowej w aspektach wyznaczonych jej zakresem badawczym, przy zastosowaniu metod badawczych przez nią wypracowanych i używanych. Mówiąc nieco inaczej - przed informacją naukową, obok innych, stoi zadanie poznania działalności informacyjnej prowadzonej w dziedzinie archiwalnej." ${ }^{31}$

Już wówczas Ryszewski postawił pytanie, czy archiwistyka ma ograniczyć swoje badania, a w zakresie problemów badawczych stawianych przez informację naukową jedynie czekać na gotowe wyniki, czy też przekroczyć granice i poszerzyć zakres problemowy zajmując się informacją archiwalną i wkraczając tym samym w krąg badawczy informacji naukowej. Równocześnie dał odpowiedź: archiwistyka już te granice przekroczyła, przejęła część specjalistycznej terminologii i w dalszym zakresie współpraca z informacją naukową może być korzystna dla obu nauk. Informacja naukowa zyskała naukę pomocniczą rozwiązującą $\mathrm{w}$ dziedzinie archiwalnej problemy przez nią stawiane, zaś archiwistyka, korzystając z teoretycznego dorobku informacji naukowej i metod

${ }^{29}$ Należy brać pod uwagę, że wiele informacji nie zostaje utrwalonych.

30 M. Dembowska, Nauka o informacji naukowej, s. 45.

31 B. Ryszewski, dz. cyt., s. 106. 
przez nią wykorzystywanych, może rozszerzyć problematykę badawczą i badać niedostrzegalne wcześniej problemy ${ }^{32}$ - czyli archiwistyka również zyskała naukę pomocniczą (czy też wspierającą) w ramach części swojego obszaru badań obejmujących działalność informacyjną.

Inne zdanie w artykule Górnego, które zwróciło moją uwagę, to: „Organizacja obiegu dokumentacji, ich klasyfikowanie, włączanie do różnych zbiorów, przetwarzanie, wyszukiwanie odpowiednich dokumentów i danych, a wreszcie ciągła pomoc użytkownikom, pisanie dla nich instrukcji, modernizowanie funkcjonujących serwisów to są obecnie zadania dla specjalistów z dziedziny informacji." 33

I zgadzam się z autorem i nie zgadzam. Moja niezgoda dotyczy przede wszystkim zignorowania przez Autora istnienia, wyodrębnionego przed siedemdziesięciu laty w Stanach Zjednoczonych, zarządzania dokumentacją (records management). W USA pierwsze archiwum federalne powołano w 1938 r., od 1940 r. zintegrowano zasady records management z funkcjami archiwów, ale obie nauki - archiwistyka oraz zarządzanie dokumentacją funkcjonują zgodnie, ale równolegle i niezależnie od tego, że są zaliczane czasem do szeroko pojmowanej nauki o informacji. Współcześnie obszar records management stanowi część informations management - zarządzania informacją, a jednocześnie pozostaje oddzielnym obszarem badawczym, działań praktycznych i dydaktycznych np. w postaci kierunków studiów na uniwersytetach. Warto zauważyć, że w warunkach społeczeństwa informacyjnego nowe pojęcie „zarządzanie informacją” zaczyna czasem zastępować starsze „zarządzanie dokumentacją”. Patrząc na zarządzanie dokumentacją czy informacją możemy je uznać za jeden z segmentów nauki o organizacji i zarządzaniu, a jednak to nie specjaliści z tej dziedziny zajmują się problemami badań w tym obszarze. To specyfika zarządzania dokumentacją stanowi o uznaniu jej dotychczasowej odrębności, a także nie zlewaniu w jeden nurt z ogólnymi zagadnieniami zarządzania informacją.

Z resztą wywodu Autora jest podobnie - widzi tylko informację i naukę o informacji jako uniwersalną i można tylko dociekać przyczyn, które stały u źródeł tej postawy. Chociaż jestem w stanie nieco Autora usprawiedliwić. Zgadzam się - chociaż nie wiem, czy taka była intencja - że współcześnie zarządzanie dokumentacją staje się coraz bardziej zarządzaniem informacją, aczkolwiek w dalszym ciągu istnieją niepodważalne podstawy, aby nie łączyć tych obszarów mających zupełnie inne korzenie: zarządzanie dokumentacją

32 Tamże, s. 107-108.

33 M. Górny, Nauka o informacji, s. 29. 
w pracy kancelarii i biurowości, archiwistyka w organizowaniu i działalności archiwów, natomiast zarządzanie informacją w informatologii, której geneza tkwi w pracy bibliotek. Jest to pewne uproszczenie, jednak od razu wskazuje na zasadnicze różnice odnośnie do przedmiotu zarządzania: w pierwszym jest to dokumentacja i archiwalia, w drugim - informacja naukowa dotycząca zasobów bibliotecznych.

Nie rozumiem, czemu służy poniższy wywód, na rzecz jakiej tezy Autor przytacza te argumenty. Czy chodzi o wchłanianie innych obszarów przez naukę o informacji?

„Żeby uczynić proces przechowywania optymalnym, musimy dysponować wiedzą z różnych dziedzin. Jak inaczej poradzimy sobie z konstrukcją pomieszczeń, w których przechowywane będą dokumenty, jak określimy warunki przechowywania (np. temperaturę, wilgotność itp.), jak będziemy kontrolować przechowywany zasób, czy nie zagrażają mu jakieś pleśnie, grzyby czy owady? A jakie działania podejmiemy, kiedy któreś z zagrożeń wystąpi?

Znajomość odpowiedzi na te pytania wiąże się z wiedzą z zakresu chemii, biologii, budownictwa, materiałoznawstwa... Czy taką wiedzę może posiąść jeden człowiek? W jakimś stopniu zapewne tak, stając się specjalistą z zakresu przechowywania dokumentów określonego typu. Tyle tylko, że ta wiedza powstawała i powstaje na obszarze kilku innych dyscyplin, przez co będzie on zapewne zmuszony do korzystania z dorobku kolegów biochemików, mikrobiologów, inżynierów budownictwa. Specjalista od przechowywania dokumentów staje się więc kimś w rodzaju agregatora wiedzy wykorzystywanej w celu realizacji określonych zadań.

W wielu dziedzinach jest podobnie. Na przykład w medycynie lekarz korzysta z wiedzy nagromadzonej m.in. przez biologów. Potrzebuje pomocy inżynierów, bo korzysta ze sprzętu o wysokim poziomie technologicznego zaawansowania. Nie jest przecież w stanie dogłębnie poznać wszystkich dziedzin, z których dorobku korzysta. Podobnie jest w przypadku specjalisty od przechowywania archiwaliów. Powstaje zatem pytanie - jak dalece trzeba znać się np. na mikrobiologii, żeby skutecznie zajmować się przechowywaniem dokumentów? Jednoznacznej odpowiedzi na to pytanie nie ma. Pewnie potrzebujemy tyle wiedzy, ile to jest niezbędne, aby osiągnąć cel, czyli przechować dokumenty w stanie względnie nienaruszonym przez odpowiednio długi czas. Będzie to prawdopodobnie wiedza, którą zdołamy posiąść w trakcie edukacji, przygotowując się do zawodu archiwisty, choć może być ona niewystarczająca, aby prowadzić efektywne badania w zakresie poprawiania mikrobiologicznych warunków przechowy- 
wania dokumentów. Taką wiedzę posiada mikrobiolog, i to on zapewne będzie prowadził badania związane z przechowywaniem dokumentów sporządzonych na określonym materiale." ${ }^{34}$

W moim przekonaniu, w praktyce archiwów oraz badaniach archiwistycznych od co najmniej kilkudziesięciu lat jest faktem specjalizacja w zakresie przechowywania i konserwacji archiwaliów różnych typów i rodzajów, o czym świadczy bogata literatura przedmiotu często będąca pokłosiem sympozjów, konferencji oraz specjalistycznych paneli w ramach np. ogólnopolskich zjazdów archiwistów. Nikt nie kwestionuje wykorzystywania w badaniach z tego zakresu zdobyczy innych nauk, jak mikrobiologii, czy chemii, podobnie, jak w przypadku dokumentacji elektronicznej podpierania się wiedzą specjalistów - informatyków. Archiwista zajmuje się gromadzeniem, przechowywaniem, opracowaniem i udostępnianiem archiwaliów ${ }^{35}$. W ramach każdej funkcji wykonywane są działania szczegółowe, wymagające specjalistycznych narzędzi i metod. Archiwiści w ramach kształcenia uniwersyteckiego zyskują wiedzę i umiejętności z każdego zakresu, ale w podejmując pracę $\mathrm{w}$ archiwach najczęściej stają się specjalistami w jednym obszarze. Nie muszą być także specjalistami od treści archiwaliów, wystarczy, że potrafią z nimi tak postępować, aby zawarta w nich informacja stała się dostępna dla użytkowników.

Na ile przytoczone wcześniej wnioski, czy propozycje Ryszewskiego są aktualne współcześnie, kiedy zarówno informacja naukowa wyrosła na działalności bibliotecznej i ośrodkach informacji naukowej, jak i archiwa wraz z całą prawie działalnością, przeniosły się do sieci, która zatarła, widoczne wcześniej, granice między nimi? Nie ma przeszkód, aby w dalszym ciągu istniała współpraca na równych prawach między archiwistyką, zarządzaniem dokumentacją i nauką o informacji, bowiem wiele obszarów pozostaje wspólnych, a wzajemne wykorzystywanie np. narzędzi badawczych może jedynie wpłynąć na lepszą skuteczność badań. Metodyka pracy archiwalnej cały czas zachowała swoją specyfikę, aczkolwiek nie wiadomo, jaka będzie np. przyszłość opracowania archiwaliów w dobie archiwów cyfrowych ${ }^{36}$.

34 Tamże, s. 24-25.

35 Są to podstawowe funkcje archiwów. Według innych kryteriów podziału archiwa pełnią funkcje naukowe i administracyjne, wewnętrzne i zewnętrzne, funkcje popularyzatorskie i edukacyjne.

36 Por. W. K. Roman, Od opisu archiwalnego do metadanych, „Archiwista Polski” nr 1-2 (85-86), 2017, s. 7-30. 
Nauka o informacji jest - na tym poziomie dyskusji - metanauką wspierającą działalność informacyjną w innych dziedzinach, jest wspólnym obszarem będącym i dalej mogącym być podstawą do współpracy. Jednak w tym miejscu może zaistnieć kolejny problem - modna od pewnego czasu w Polsce, a na świecie od kilkunastu lat - architektura informacji.

W tym miejscu po raz drugi cytat z tekstu Górnego już wcześniej przywołany:

„Organizacja obiegu dokumentacji, ich klasyfikowanie, włączanie do różnych zbiorów, przetwarzanie, wyszukiwanie odpowiednich dokumentów i danych, a wreszcie ciągła pomoc użytkownikom, pisanie dla nich instrukcji, modernizowanie funkcjonujących serwisów to są obecnie zadania dla specjalistów z dziedziny informacji." ${ }^{\prime 3}$

Użycie terminu „serwisy” sugeruje wprost, że chodzi o zawartość sieci. I w tym miejscu zgadzam się, że specjaliści z dziedziny informacji, czy też architekci informacji powinni współdziałać z archiwistami przy tworzeniu archiwalnych stron internetowych, ale przede wszystkim przy budowie archiwalnych serwisów informacyjnych czy po prostu systemu informacji archiwalnej opartego o narzędzia informatyczne. W ostatnich latach niekoniecznie ta współpraca się sprawdzała, czy też na tym poziomie w ogóle jej nie było, a na współpracy/ /dominacji z informatykami, archiwalny system informacji dobrze nie wyszedł.

Dlatego architektura informacji jako „metadyscyplina obejmująca projektowanie, implementację i utrzymywanie przestrzeni informacji cyfrowej udostępnianej człowiekowi”"38

bądź jako „sztuka i nauka konstruowania i klasyfikowania stron internetowych i intranetowych, których celem jest pomoc w znajdowaniu i zarządzaniu informacją oraz proces organizowania, etykietowania, projektowania nawigacji i systemów wyszukiwawczych pomocnych w znajdowaniu i zarządzaniu informacją"39 może współcześnie wspomagać archiwa w udostępnianiu informacji w sieci. Nie należy jednak uważać, że architekt informacji zastąpi archiwistę, chociaż jego pomoc może wspomóc archiwistę w jego działaniach na rzecz użytkownika w sieci.

Jednak tu też widzę pewne niebezpieczeństwo. Otóż architektura informacji reprezentowana i interpretowana przez autora kilku polskich publikacji na ten

37 M. Górny, Nauka o informacji, s. 29.

38 S. Skórka, Architektura informacji - sztuka czy rzemiosło, https://www.slideshare. net/skorkas/skorka-stanislaw-ai-dziedzina-czy-rzemioso (dostęp: 15.06.2018)

39 P. Morville, L. Rosenfeld, Information Architecture for World Wide Web: Designing Large Scale Web Sites, 1998, za: S. Skórka, Architektura informacji, dz. cyt. 
temat, dr. Stanisława Skórkę, odkrywa m.in. coś, czym od kilkaset lat zajmuje się dyplomatyka jako nauka o dokumencie. Podczas konferencji archiwalnej dr Skórka przedstawił budowę dokumentu jako obszar działania architekta informacji w taki sposób, jakby dokumenty pojawiły się dopiero w epoce sieci ${ }^{40}$. Jest zrozumiałe, że budowa/struktura dokumentu elektronicznego jest różna od tradycyjnego, niektóre elementy struktury tradycyjnej mogą być również częścią metadanych, a nie fragmentem treści, jednak to raczej dyplomatyka powinna (i już to robi ${ }^{41}$ ) przystosować swój warsztat badawczy do badania współczesnych dokumentów ${ }^{42}$. Architektura informacji zaś znakomicie sprawdzi się w szerszym zakresie - struktury rozmieszczenia różnych informacji w sieci oraz narzędzi wspomagających ich wyszukiwanie.

Dlaczego dzisiaj trzeba stawać w obronie odrębności archiwistyki czy zarządzania dokumentacją? Jak silne są tendencje do wchłonięcia obszaru działań zachodzących podczas procesu aktotwórczego i archiwotwórczego oraz działalności archiwów przez - nie da się ukryć - swego rodzaju molocha, jakim jest, czy też jakim ma się stać w oczach niektórych, nauka o informacji? Być może od razu stawiam swoje wywody na straconej pozycji, gdyż nauka o informacji została uznana za samodzielną dyscyplinę naukową ${ }^{43}$ natomiast ani archiwistyka, ani zarządzanie dokumentacją nie istnieją formalnie na liście dyscyplin opracowanej przez Ministerstwo Nauki i Szkolnictwa Wyższego. Dlaczego? Przyczyn jest kilka. Bodajże najważniejszą $\mathrm{z}$ nich jest $\mathrm{w}$ dalszym ciągu mocne powiązanie $\mathrm{z}$ historią i postrzeganie archiwistyki jedynie jako jej nauki pomocniczej odmawiając jej cech charakterystycznych dla samodzielnej dyscypliny, o czym do końca był

40 S. Skórka, Architektura informacji w systemach zarządzania dokumentami, VII Toruńskie Spotkania Archiwalne, Toruń 24 V 2018, http://www.arch.umk.pl/program1. html (dostęp: 30.05.2018).

${ }^{41}$ Por. np. Belliculum diplomaticum VI Thorunense. Od dyplomatyki i archiwistyki do dokumentu elektronicznego, red. K. Kopiński, J. Tandecki, Toruń 2016.

${ }^{42}$ Pisał o tym m.in. Krzysztof Skupieński: Pytania o definicje dokumentu, kancelarii i archiwum w „epoce bez papieru” [w:] Zatrzymać przeszłość, dogonić przyszłość: pamiętnik VI Powszechnego Zjazdu Archiwistów Polskich, Wrocław 5-7 września 2012 r., red. Waldemar Chorążyczewski, Krzysztof Stryjkowski, red. W. Chorążyczewski, K. Stryjkowski, Warszawa 2013, s. 243-255.

43 Jako bibliologia i informatologia widnieje w Rozporządzeniu Ministra Nauki i Szkolnictwa Wyższego z dnia 8 sierpnia 2011 r. w sprawie obszarów wiedzy, dziedzin nauki i sztuki oraz dyscyplin naukowych i artystycznych. Dz. U. z dnia 30 sierpnia 2011 r. Pod poz. 5.8.b. jako „Nauka o informacji” figuruje w Wykazie dziedzin nauki i technik wedtug klasyfikacji OECD, https://www.ncbr.gov.pl/fileadmin/user_upload/import/tt_content/files/ 2_wykaz_dziedzin_nauki_i_technik_wedlug_klasyfikacji_oecd.pdf (dostęp: 15.02.2018). 
przekonany np. wybitny znawca nauk pomocniczych historii Józef Szymański ${ }^{44}$. Z kolei Waldemar Chorążyczewski upatruje ich w przedmiocie badań:

Archiwistyka jest przede wszystkim nauką stosowaną, a więc obliczoną na przełożenie teorii na praktykę. Z tego względu przez purystów może nie być w ogóle uważana za naukę. W klasycznej metodologii badań naukowych uważa się przecież, iż podmiot badający (uczony) nie może ingerować w przedmiot badań. Tymczasem archiwistyka najpierw kształtuje swój przedmiot badań (czyli archiwa, choćby poprzez kształcenie archiwistów), a następnie przystępuje do formułowania twierdzeń odnośnie swego przedmiotu badań ${ }^{45}$.

Może my - archiwiści, czy przede wszystkim środowisko badaczy zgłębiających od lat zagadnienia archiwistyki i zarządców dokumentacją - nie jesteśmy wystarczająco zdeterminowani, aby zbudować lobby na rzecz wyemancypowania nauk, które uprawiamy?

Tendencje w kierunku zawłaszczania przez naukę o informacji obszaru badań właściwego dla zarządzania dokumentacją i archiwistyki są niebezpieczne o tyle, że niweczą wieloletni dorobek obu tych nauk, niebezpieczne, ponieważ dokumentacja powstająca $\mathrm{w}$ urzędach, instytucjach, która kiedyś stanie się archiwaliami, posiada swoją specyfikę, której nie zmieniły nowe technologie. Ich różnorodność wymaga specjalistycznych metod postępowania, i chociaż każdy dokument może dziś istnieć $\mathrm{w}$ formie elektronicznej, to nic nie traci z tego, czym jest $\mathrm{w}$ istocie dla archiwistyki - dokumentem tekstowym, mapą, filmem czy nagraniem. Oczywiście takie instytucje, jak archiwa, biblioteki, a także muzea, czy ośrodki dokumentacyjne łączy wiele podobieństw, ale i zasadnicze różnice, które wpływają na fakt, że funkcjonują one odrębnie, a archiwa państwowe wśród nich na szczególnym statusie jako urzędy administracyjne.

Powyższe rozważania mają charakter dyskusyjny. Z tego względu np. wybór literatury przywoływanej w przypisach nie ma charakteru całościowego i nie jest pełną bazą bibliograficzną, a służy jedynie ilustracji przedstawionych wywodów. Te zaś może skłonią do zastanowienia się nad kondycją archiwistyki i zarządzania dokumentacją, jeśli nawet to tylko zewnętrzne postrzeganie obu obszarów przez przedstawicieli nauki o informacji uległo zmianie. Może jednak moje obawy są tylko konserwatywnym okopywaniem się na pozycjach? Niewykluczone, że za jakiś czas spojrzę inaczej nie tylko na tekst Mirosława

44 Por. m.in. J. Szymański, Nauki pomocnicze historii, Warszawa 2001, s. 504-525.

45 W. Chorążyczewski, Archiwistyka dla początkujących (wersja 1), Toruń 2014, https://repozytorium.umk.pl/bitstream/handle/item/2191/Archiwistyka_dla_poczatkujacych_wersja_1.pdf?sequence=1 (dostęp: 17.02.2018). 
Górnego, ale i na swój, a także na zmiany zachodzące w archiwistyce i nauce o informacji.

\section{Bibliografia}

Batorowska, Hanna, Barbara Czubała. Wybrane zagadnienia nauki o informacji i technologii informacyjnej. Kraków: Wydawnictwo Naukowe WSP, 1996.

Buckland Michael Keeble, Ziming Liu. „History of information science.” Annual Review of Information Science and Technology 30 (1995): 385-416.

Burke, Colin. „History of Information Science.” Annual Reviev of Information Science and Technology 41, nr 1 (2007): 3-53. https://doi.org/10.1002/aris.2007.1440410108.

Chorążyczewski, Waldemar. Archiwistyka dla początkujących. Toruń, 2014. https:// repozytorium.umk.pl/bitstream/handle/item/2191/Archiwistyka_dla_poczatkujacych_wersja_1.pdf? sequence $=1$.

Cisek, Sabina. „Informatologia w drugim dziesięcioleciu XXI w. Przedmiot, pole badawcze i miejsce w systemie nauk. Aneks. 2: Nauka o informacji, czyli o czym?" Opublikowane 4.10.2013. https://www.slideshare.net/sabinacisek/cisek-xii-forum-2013.

Cisek, Sabina. „Podstawy teorii i metodologii informatologii.” Opublikowane 1.10.2016. http://docplayer.pl/63276812-Podstawy-teorii-i-metodologii-informatologii.html.

Dembowska, Maria. Dokumentacja i informacja naukowa: zarys problematyki i kierunki rozwoju. Warszawa: Stowarzyszenie Bibliotekarzy Polskich, 1965.

Dembowska, Maria. Nauka o informacji naukowej (informatologia): organizacja i problematyka badań $w$ Polsce. Warszawa: IINTE, 1991.

Fajgielski, Pawet. Informacja $w$ administracji publicznej: prawne aspekty gromadzenia, udostępniania i ochrony. Wrocław: Presscom, 2007.

Gołembiowski, Maciej. System informacji archiwalnej. Warszawa; Łódź: Państwowe Wydawnictwo Naukowe, 1985.

Gołembiowski, Maciej. Wprowadzenie do informacji naukowej dla archiwistów. Toruń: Uniwersytet Mikołaja Kopernika, 1991.

Górny, Mirosław. „Nauka o informacji jako dyscyplina naukowa.” W Nauka o informacji, red. Wiesław Babik, 23-40. Warszawa: Wydawnictwo Stowarzyszenia Bibliotekarzy Polskich, 2016.

Górny, Mirosław, Piotr Nowak. Wstęp do informacji naukowej. Poznań: [Uniwersytet im. Adama Mickiewicza], 1989.

Górny, Mirosław. „O formułowaniu problemów badawczych w nauce o informacji.” W Nauka o informacji w okresie zmian, red. Barbara Sosińska-Kalata, Ewa Chuchro przy współpr. Mariusza Luterka, 43-51.Warszawa: Wydawnictwo Stowarzyszenia Bibliotekarzy Polskich, 2013.

Janiak, Małgorzata. Informacja naukowa w Polsce na przełomie XX i XXI wieku: dynamika zmian $w$ świetle piśmiennictwa. Kraków: Wydawnictwo Uniwersytetu Jagiellońskiego, 2010. 
Kopiński, Krzysztof, Janusz Tandecki, red. Belliculum diplomaticum VI Thorunense: od dyplomatyki i archiwistyki do dokumentu elektronicznego. Toruń: Towarzystwo Naukowe, 2016.

Kulikowski, Juliusz Lech. Informacja i świat, w którym żyjemy. Warszawa: „Wiedza Powszechna", 1978.

Leska, Maria, Kazimierz Leski. „Informacja naukowa jako dziedzina wiedzy.” Zagadnienia Informacji Naukowej" 20 (1972): 7-28.

Morville, Peter, Louis Rosenfeld, Information Architecture for World Wide Web: Designing Large Scale Web Sites. 1998.

Nawrocki, Stanisław, „Archiwum jako ośrodek informacji.” W Stanisław Nawrocki. Archiwistyka i regionalizm, 285-296. Poznań: Instytut Historii Uniwersytetu im. Adama Mickiewicza, 1995.

Narodowe Centrum Badań i Rozwoju. „Wykaz dziedzin nauki i technik według klasyfikacji OECD.” Dostęp 15.02.2018. https://www.ncbr.gov.pl/fileadmin/user_upload/import/ tt_content/files/2_wykaz_dziedzin_nauki_i_technik_wedlug_klasyfikacji_oecd.pdf.

Oleński, Józef. Ekonomika informacji: metody. Warszawa: Polskie wydawnictwo Ekonomiczne, 2003.

Oleński, Józef. Ekonomika informacji: podstawy. Warszawa: Polskie Wydawnictwa Ekonomiczne, 2001.

Pepłowska, Katarzyna. Archiwa cyfrowe w wybranych krajów europejskich, USA i Australii. Toruń: Wydawnictwo Naukowe Uniwersytetu Mikołaja Kopernika, 2017.

Piróg, Wojciech. Zagadnienia informacji i dokumentacji naukowej. Warszawa: Państwowe Wydawnictwo Naukowe, 1977.

Czekaj, Janusz, red. Podstawy zarządzania informacją. Kraków: Wydawnictwo Uniwersytetu Ekonomicznego, 2012.

Ratajewski, Jerzy. Wybrane problemy metodologiczne informologii nauki (informacji naukowej). Katowice: Wydawnictwo Uniwersytetu Śląskiego, 1994.

Robótka, Halina, red. Współczesna biurowość w administracji publicznej. Toruń: Wydawnictwo Naukowe Uniwersytetu Mikołaja Kopernika, 2013.

Robótka, Halina. Wspótczesna biurowość: zagadnienia ogólne. Toruń: Wydawnictwo Naukowe Uniwersytetu Mikołaja Kopernika, 2010.

Robótka, Halina, red. Współczesna dokumentacja urzędowa. Toruń: Wydawnictwo Naukowe Uniwersytetu Mikołaja Kopernika, 2011.

Roman, Wanda Krystyna. „Od opisu archiwalnego do metadanych.” Archiwista Polski 22, $\operatorname{nr} 1-2$ (2017): 7-30.

Roman, Wanda Krystyna. Współczesna kultura dokumentacyjna. Toruń: Wydawnictwo Naukowe Uniwersytetu Mikołaja Kopernika, 2013.

Rudecka-Onichimowska, Barbara., Poradnik metodyczny do nauki przedmiotu „Źródła informacji, działalność informacyjna”. Warszawa: Centrum Ustawicznego Kształcenia Bibliotekarzy, 1997.

Ryszewski, Bohdan. Problemy i metody badawcze archiwistyki. Toruń: Uniwersytet Mikołaja Kopernika, 1985. 
Skórka, Stanisław. „Architektura informacji - sztuka czy rzemiosło.” Opublikowano 17.100.2007. https://www.slideshare.net/skorkas/skorka-stanislaw-ai-dziedzina -czy-rzemioso.

Skupieński, Krzysztof. „Pytania o definicje dokumentu, kancelarii i archiwum w epoce bez papieru." W Zatrzymać przeszłość, dogonić przyszłość: pamiętnik VI Powszechnego Zjazdu Archiwistów Polskich, Wrocław 5-7 września 2012 r., red. Waldemar Chorążyczewski, Krzysztof Stryjkowski, 243-255. Warszawa: Stowarzyszenie Archiwistów Polskich, 2013.

Sosińska-Kalata, Barbara. „Ewolucja koncepcji informatologii (nauki o informacji).” W Teoretyczne zagadnienia bibliologii i informatologii: studia i szkice, red. Elżbieta Gondek, 115-137. Katowice: Wydawnictwo Uniwersytetu Śląskiego, 2015.

Sosińska-Kalata, Barbara. „Współczesne oblicze nauki o informacji w Polsce i za granicą.” W Studia z informacji naukowej i dyscyplin pokrewnych: prace dedykowane profesor Barbarze Stefaniak, red. Elżbieta Gondek, Diana Pietruch-Reizes, 93-119. Katowice: Wydanwictwo Uniwersytetu Śląskiego, 2007

Stryjkowski, Kazimierz. Vademecum kancelaryjno-archiwalne. Poznań: Wydawnictwo Rys, 2011.

Szymański, Józef. Nauki pomocnicze historii. Warszawa: Wydawnictwo Naukowe PWN, 2001.

Tomczak, Andrzej. „Archiwistyka polska (1918-1969): z dziejów kształtowania się dyscypliny naukowej i jej nazwy." Rocznik Biblioteki Narodowej 7 (1972): 127-159.

Zygała, Ryszard. Podstawy zarządzania informacja $w$ przedsiębiorstwie. Wrocław: Wydawnictwo Akademii Ekonomicznej im Oskara Langego, 2007. 
